AL IBTIDA: JURNAL PENDIDIKAN GURU MI (2018) Vol 5 (1): 11-24

DOI: http://dx.doi.org/ 10.24235/al.ibtida.snj.v5i1.2456

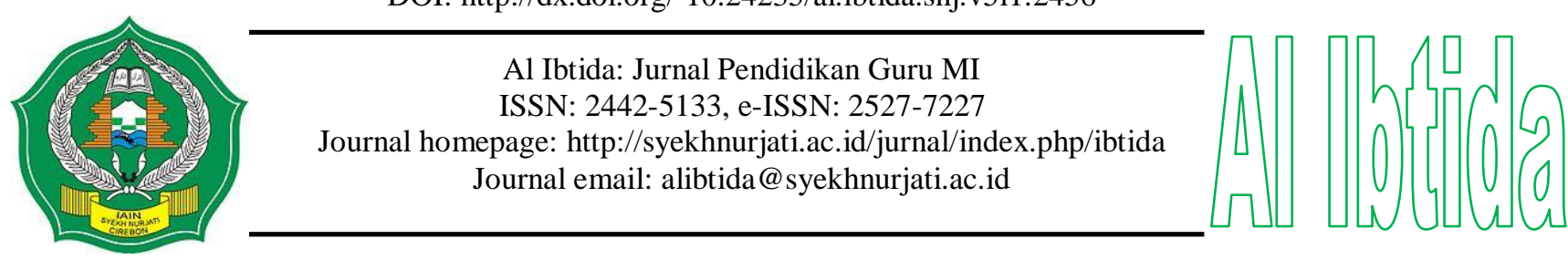

\title{
Optimalisasi Karakter Positif Calon Guru MI Melalui Lesson Plan Berbasis ARCS pada Mahasiswa Micro Teaching PGMI IAIN Syekh Nurjati Cirebon
}

\author{
Tati Nurhayati* \\ *Program Studi Pendidikan Guru Madrasah Ibtidaiyah, Fakultas Ilmu Tarbiyah dan Keguruan, \\ IAIN Syekh Nurjati Cirebon \\ Email: tatinurhayati674@gmail.com
}

Received 31 January 2018; Received in revised form: 02 April 2018; Accepted 12 April 2018

Publish Online: 28 June 2018

\begin{abstract}
Abstrak
Mengkaji fenomena di masyarakat dan media sosial dewasa ini semakin maraknya tindakan amoral serta degradasi moral pada anak-anak di sekolah. Faktor-faktor resiko bukan hanya terletak pada kecerdasan otak tetapi pada karakter. Mahasiswa PGMI yang mengikuti matakuliah micro teaching disiapkan untuk menjadi calon pendidik yang nantinya akan mengawal para generasi emas menggapai masa depan yang lebih baik dengan ditunjang karakter yang mulia.Tujuan penelitian ini adalah untuk memperoleh data tentang pengembangan pendidikan karakter melalui pendekatan ARCS dalam lesson plan, bagaimana penerapan karakter melalui pendekatan ARCS dalam lesson plan, dan bagaimana implikasi pendidikan karakter calon guru MI melalui pendekatan ARCS dalam lesson plan. Penelitian ini menggunakan pendekatan kualitatif dengan metode penelitian tindakan kelas (PTK). Teknik pengumpulan data melalui observasi, wawancara, dokumentasi dan tes. Sementara itu teknik analisis data yang digunakan adalah analisis deskriptif dan uji t tes. Hasil penelitian menunjukkan bahwa penggunaan model ARCS mampu membangkitkan perhatian peserta didik pada proses pembelajaran, menunjukkan hubungan materi pelajaran dengan kebutuhan, meningkatkan rasa percaya diri, dan menciptakan kepuasan peserta didik dalam pembelajaran. Selain itu, penggunaan model ARCS juga mampu meningkatkan hasil belajar peserta didik, yakni nilai rata-rata peserta didik mencapai 85 .
\end{abstract}

Kata kunci: optimalisasi, karakter, ARCS, lesson plan

\begin{abstract}
The phenomenon of studying in society and social media today is increasingly widespread immoral acts and moral degradation in children in school. Risk factors not only lie with the intelligence of the brain but on the characters. The Student of PGMI who follow the micro teaching course are prepared to become candidate of educators who will be guarding the gold generation to reach a better future supported by noble character. The purpose of this research is to obtain data about character education development through ARCS approach in lesson plan, how the application of character through the ARCS approach in the lesson plan, and how the educational implications of MI candidate teacher
\end{abstract}


character through ARCS approach in the lesson plan. This research uses a qualitative approach with classroom action research methods (PTK). The technique of collecting data through observation, interview, documentation and test. Meanwhile, the technique of analysis data used is descriptive analysis and test $t$ test. The results showed that the use of ARCS model is able to arouse the attention of learners in the learning process, showing the relation of the subject matter with the needs, increase the confidence, and create the satisfaction of learners in learning. In addition, the use of ARCS model is also able to improve learning outcomes of learners, namely the average value of students reached 85 .

Keywords: optimization, character, ARCS, lesson plan

\section{PENDAHULUAN}

Berdasarkan fenomena di masyarakat juga dari berbagai literatur sekarang ini banyak memberitakan tindakan amoral serta masih banyaknya varian degradasi (penurunan) moral dari anak-anak di sekolah sebagai contoh semakin banyaknya kasus bullying (Freeman, 2014). Kasus kekerasan fisik pada anak usia dini maupun kasus pelecehan seksual yang dilakukan oleh anakanak semakin meningkat. Maswardi (2011) mengatakan bahwa faktor-faktor resiko yang disebutkan ternyata bukan terletak pada kecerdasan otak, tetapi pada karakter. Resiko pada karakter tersebut yaitu rasa percaya diri, kemampuan bekerja sama, kemampuan bergaul, kemampuan berkonsentrasi, rasa empati, kemampuan berkomunikasi, kejujuran, disiplin, tanggung jawab, toleransi dan sebagainya.

Sebaliknya, para remaja yang mempunyai karakter baik atau mempunyai kecerdasan emosi tinggi akan terhindar dari masalah-masalah umum yang dihadapi oleh remaja seperti kenakalan, tawuran, narkoba, miras, perilaku seks bebas, dan sebagainya. Goleman (1995) juga mengatakan bahwa banyak orang tua yang kurang berhasil dalam mendidik karakter anakanaknya. Padahal orangtua dalam keluarga merupakan lembaga yang utama dan pertama serta bertanggung jawab penuh terhadap karakter anak. Pernyataan ini juga diperkuat oleh Helmawati (2014) yang mengatakan bahwa keluarga merupakan tempat di mana anak pertama kali berkenalan, mengenal lingkungannya dan berpengaruh terhadap perkembangan anak selanjutnya.

Namun menurut Lickona (1991) pendidikan karakter bukan saja sebagai tanggung jawab orang tua ataupun guru agama saja, akan tetapi juga semua pihak yang berkepentingan serta terkait dengan peserta didik. Bahkan dalam langkah selanjutnya menurut Power (2011) pendidikan karakter perlu dilaksanakan oleh seluruh lapisan masyarakat, di seluruh instansi pemerintah, ormas, partai politik, lembaga swadaya masyarakat, perusahan dan kelompok masyarakat lainnya. Selain itu, dalam pelaksanaannya di lapangan, pendidikan karakterpun memerlukan peneladanan dan pembiasaan dari pihak-pihak tersebut.

Untuk mempertajam analisis pernyataan ini perlu mengetahui definisi pendidikan karakter. Pendidikan karakter adalah upaya penciptaan lingkungan sekolah yang membantu 
peserta didik dalam pengembangan etika dan tanggung jawab melalui model dan pengajaran karakter yang baik yang merupakan nilai-nilai universal (Berkowits, 2005). Sedangkan pendidikan karakter menurut Wibowo (2012) adalah pendidikan yang menerapkan dan mengembangkan karakter-karakter luhur kepada peserta didik dan mengaplikasikannya dalam kehidupan baik di keluarga, masyarakat maupun negara. Kesimpulan pengertian pendidikan karakter menurut pendapat paradigma adalah pendidikan karakter merupakan sistem penanaman nilai-nilai karakter kepada peserta didik sehingga mereka menerapkan dalam kehidupannya baik di keluarga, sekolah, masyarakat, dan negara sehingga mampu memberikan sumbangsih positif kepada lingkungannya.

Secara lebih terperinci, menurut Suyadi (2016) terdapat 18 nilai karakter yang dikembangkan oleh kementerian Pendidikan nasional, yaitu religius, jujur, toleransi, disiplin, kerja keras, kreatif, mandiri, demokratis, rasa ingin tahu, semangat kebangsaan atau nasionalisme, cinta tanah air, menghargai prestasi, komunikatif, cinta damai, gemar membaca, peduli lingkungan, peduli sosial dan tanggung jawab. Adapun urgensi penguatan pendidikan karakter positif bagi calon guru MI yaitu: (1) pembangunan sumber daya manusia merupakan pondasi pembangunan bangsa; (2) keterampilan abad 21 yang dibutuhkan siswa terdiri dari kualitas karakter, literasi dasar, dan kompetensi dalam rangka mewujudkan keunggulan dan bersaing generasi emas 2045; dan (3) kecenderungan kondisi degradasi moralitas, etika, dan budi pekerti (Permendikbud, 2015).

Mengkaji permasalahan tersebut di atas peneliti terdorong untuk melakukan kajian tentang upaya optimalisasi pendidikan karakter melalui pendekatan ARCS dalam lesson plan bagi mahasiswa PGMI IAIN Syekh Nurjati Cirebon yang mengikuti matakuliah micro teaching. Lesson plan adalah suatu rencana yang menggambarkan prosedur dan pengorganisasian pembelajaran untuk mencapai satu kompetensi dasar (KD) yang ingin dicapai dan ditetapkan dalam standar isi serta dijabarkan dalam silabus (Hernawan, 2009). Lingkup lesson plan paling luas mencakup satu KD yang terdiri atas satu indikator atau beberapa indikator untuk satu kali pertemuan atau lebih (Munthe, 2009). Adapun konsepsi lesson plan berdasarkan pendekatan ARCS merupakan salah satu pendekatan dalam model motivational design for learning and performance. Di mana pendekatan ini merupakan akronim dari attention, relevance, confidence dan satisfaction. ARCS sebagai model pendekatan dalam pembelajaran yang sarat dengan muatan motivasi belajar yang dikembangkan oleh Keller dan Kopp pada tahun 1987 (Keller, 2010). Sejalan dengan pemikiran tersebut Wu, Tsai, Yang, Huang, dan Lin (2012) meyakini dengan hasil penelitiannya bahwa pembelajaran dengan model ARCS dapat memberikan 
motivasi yang cukup tinggi dikalangan mahasiswa sehingga daya juang dan kompetisinya semakin meningkat.

Dengan penelitian ini peneliti berupaya menyiapkan calon pendidik yang nantinya akan mengawal pada generasi emas (Sariono, 2013) dalam menggapai masa depan. Sehingga keresahan beberapa pakar pendidikan anak serta orang tua akan pendidikan anaknya yang kemudian direspon positif oleh pemerintah hingga lahirlah kurikulum 2013. Menurut peneliti, diantara solusi pembelajaran dalam kurikulum yang dapat digunakan untuk menjawab permasalahan tersebut salah satunya adalah dengan menggunakan pendidikan karakter yang berbasis lesson plan dengan menggunakan pendekatan ARCS.

Dengan demikian diharapkan guru mampu mengemas atau merancang pengalaman belajar yang akan mempengaruhi kebermaknaan siswa serta kesesuaian dengan tahapan relevansi dengan sekitarnya. Pengalaman belajar yang menunjukkan kaitan unsur-unsur konseptual menjadikan proses pembelajaran lebih efektif. Kaitan konseptual antar mata pelajaran yang dipelajari akan membentuk skema sehingga siswa akan memperoleh keutuhan dan kebulatan pengetahuan. Selain itu penerapan lesson plan ini pada sekolah dasar akan sangat membantu siswa, karena sesuai dengan tahap perkembangan siswa yang masih berfikir holistik dan membutuhkan motivasi serta dukungan dari lingkungan sekitarnya (Uno, 2006).

Selain beberapa ekspektasi di atas, peneliti mengharapkan terdapat peningkatan dan pengembangan dalam karakter mahasiswa PGMI dan calon guru yang mampu mengantarkan anak didiknya menjadi sebuah generasi yang secara intelektual melek IT, produktif dan inovatif serta secara sosio kultural bermartabat, berakhlak mulia, berintegritas, berperadaban unggul namun tetap santun sebagai bangsa yang beradab.

Adapun tujuan dari penelitian ini adalah untuk a) mengkaji pola optimalisasi pendidikan karakter calon guru MI melalui pendekatan ARCS dalam Lesson Plan bagi mahasiswa PGMI yang mengikuti matakuliah micro teaching; b) mengetahui bagaimana upaya optimalisasi pendidikan karakter calon guru MI melalui pendekatan ARCS dalam Lesson Plan bagi mahasiswa PGMI yang mengikuti matakuliah micro teaching; c) menganalisis implikasi pendidikan karakter calon guru MI melalui pendekatan ARCS dalam Lesson Plan terhadap mahasiswa PGMI yang mengikuti matakuliah micro teaching.

\section{METODE PENELITIAN}

Penelitian ini menggunakan pendekatan kualitatif dengan metode penelitian tindakan kelas atau yang dikenal dengan Classroom action research. Menurut Kasbolah (1999: 15) mengemukakan bahwa penelitian tindakan kelas adalah penelitian tindakan dalam bidang pendidikan yang dilaksanakan dalam kawasan kelas dengan tujuan untuk memperbaiki atau 
meningkatkan kualitas pembelajaran. Menurut Arikunto (2008: 16) desain PTK diilustrasikan dengan gambar sebagai berikut:

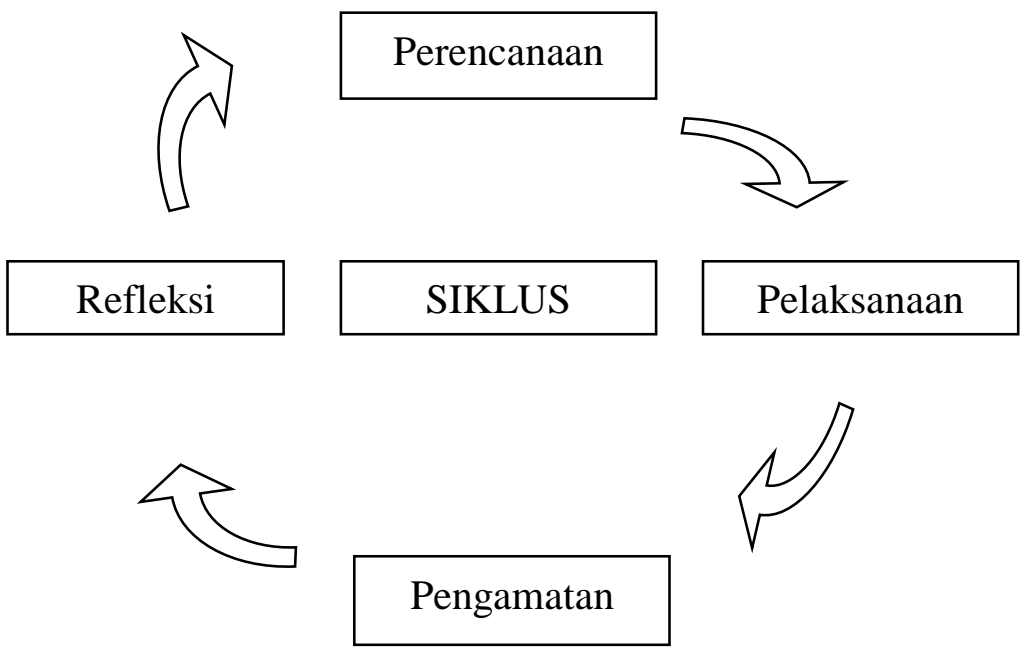

Secara lebih rinci, prosedur penelitian tindakan kelas sebagai berikut (Mulyasa, 2009):

1. Tahap perencanaan meliputi: a) peneliti mengadakan penelitian awal mengungkap permasalahan pembelajaran; b) membuat RPP; c) menyiapkan media pembelajaran; d) menyusun instrumen penelitian antara lain: soal tes hasil belajar, lembar observasi, wawancara, dan catatan lapangan.

2. Tahap pelaksanaan yakni melaksanakan sesuai yang telah direncanakan seperti menerapkan pendekatan maupun metode pembelajaran dengan alat peraga sesuai dengan perencanaan.

3. Tahap observasi yakni dilakukan selama kegiatan belajar mengajar dengan mengamati aktivitas guru dan aktivitas peserta didik.

4. Tahap analisis dan refleksi yakni data yang diperoleh dari data penilaian hasil belajar, observasi, wawancara dan catatan lapangan dikumpulkan dan dianalisis untuk dijadikan penyusunan program selanjutnya dengan langkah sebagai berikut : a) analisis, sintesis dan interpretasi terhadap semua data dan fakta selama pelaksanaan tindakan; b) melakukan evaluasi terhadap keberhasilan dan pencapaian tindakan; c) memperbaiki proses pembelajaran.

Adapun yang menjadi fokus penelitian adalah pada pendidikan karakter melalui pendekatan ARCS dalam lesson plan untuk mengoptimalkan karakter melalui desain lesson plan ARCS bagi calon guru MI agar bisa memiliki daya saing dan daya juang dalam mengajar di kelas. Subjek informan dilakukan melalui teknik sampling dengan menggunakan purposive sampling (Arikunto, 1998: 102). Teknik pengumpulan data melalui observasi, wawancara 
mendalam, dokumentasi, dan tes. Sedangkan teknik analisis data menggunakan analisis deskriptif kualitatif dan uji t tes.

\section{HASIL DAN PEMBAHASAN}

\section{Pola Optimalisasi Pendidikan Karakter Calon Guru MI melalui Pendekatan ARCS}

Dalam pelaksanaan pembelajaran di kelas, seorang guru harus mampu menyajikan proses pembelajaran dengan baik dan dapat menciptakan kondisi belajar yang efektif. Guru juga harus mampu membangkitkan motivasi belajar peserta didik. Dengan motivasi belajar yang tinggi, peserta didik akan berkonsentrasi mengikuti kegiatan pembelajaran di kelas dan membangkitkan semangat belajar demi mencapai tujuan yang diharapkan. Berkaitan dengan hal tersebut, mahasiswa PGMI yang dalam hal ini merupakan mahasiswa praktikan micro teaching dengan dukungan peneliti telah mengimplementasikan model ARCS dalam kelas praktik pada saat siklus ketiga, salah satunya dengan berusaha membangkitkan perhatian, menunjukkan hubungan materi pelajaran dengan kebutuhan, meningkatkan rasa percaya diri, dan menciptakan kepuasan peserta didik dalam pembelajaran.

Adapun pola implementasi model ARCS dalam pembelajaran di kelas praktik micro teaching yang telah dilaksanakan adalah sebagai berikut:

\section{a. Attention (Perhatian)}

Aspek perhatian yang dimaksud dalam kelas praktik ini dilakukan dengan cara pemusatan konsentrasi kepada suatu objek, dalam hal ini peristiwa proses belajar mengajar di kelas. Mahasiswa yang perasaannya senang dan bahagia akan terbantu konsentrasi belajarnya, begitu pula sebaliknya mahasiswa dalam kondisi tidak senang, akan kurang berminat dalam belajarnya dan kesulitan untuk berkonsentrasi terhadap proses pembelajaran yang sedang berlangsung.

Adapun peran peneliti di sini sebagai dosen pembimbing selalu berusaha membangkitkan perhatian peserta didik dalam proses pemebelajaran, karena perhatian merupakan hal yang sangat penting guna menumbuhkan keingintahuan peserta didik yang diperlukan dalam kegiatan pembelajaran. Sehingga mereka akan berkonsentrasi terhadap materi yang disampaikan, yang pada akhirnya akan mempengaruhi hasil belajarnya.

Terkait dengan membangkitkan perhatian peserta didik dalam pembelajaran, guru dapat memotivasi dengan menggunakan 1) metode pembelajaran yang menarik dan bervariasi; 2) media pembelajaran yang dapat meningkatkan perhatian dan motivasi belajar; dan 3) pemberian contoh berdasar peristiwa nyata dalam kehidupan sehari-hari; serta 4) pemberian kesempatan bertanya kepada peserta didik. 


\section{b. Relevance (kegunaan)}

Relevansi yang dimaksud dalam penelitian ini adalah adanya hubungan antara bahan ajar dengan kebutuhan dan kondisi peserta didik. Jika mereka merasa tidak membutuhkan suatu pelajaran tertentu, maka akan menganggap pelajaran tersebut tidak penting sehingga motivasi mereka untuk belajar sangat kecil. Motivasi belajar peserta didik akan muncul jika mereka mengetahui apa yang dipelajari memiliki manfaat dan berhubungan dengan kehidupan sehari-hari.

Dari hasil penelitian, dapat diketahui bahwa motivasi yang diberikan oleh mahasiswa praktikan dalam menunjukkan hubungan materi pelajaran dengan kebutuhan peserta didik yakni melalui; 1) tujuan; 2) manfaat; dan 3) antusiasisme.

\section{c. Confidence (percaya diri)}

Rasa percaya diri merupakan suatu keyakinan bahwa dirinya mampu untuk melakukan sesuatu. Dengan adanya rasa percaya diri yang tinggi peserta didik akan merasa bahwa dirinya akan mampu melakukan tantangan apapun, sehingga termotivasi untuk mengejar cita-citanya dengan giat belajar. Dalam meningkatkan rasa percaya diri peserta didik, guru juga harus selalu berusaha menghilangkan rasa kekhawatiran dan ketidakmampuan dalam diri mereka dengan meyakinkan untuk menyadari kekuatan dan kelemahan diri serta menanamkan gambaran diri positif terhadap diri sendiri. Dari hasil penelitian, didapatkan bahwa mahasiswa praktikan juga selalu meningkatkan kepercayaan diri peserta didik dengan; 1) berpikirk kesuksesan; 2) menyusun skenario pembelajaran 3) umpan balik (Feed back) antara peserta didik dengan guru.

\section{d. Satisfaction (kepuasan)}

Kepuasan yang dimaksud dalam konsep ARCS ini merupakan perasaan senang karena telah berhasil melakukan sesuatu yang menghasilkan penghargaan terhadap dirinya. Perasaan ini perlu ditanamkan kepada peserta didik yang telah berhasil mengerjakan sesuatu sehingga pada akhirnya akan mendorong mereka untuk mengulangi keberhasilannya dalam kesempatan lainnya.

Berdasarkan hasil penelitian, diperoleh hasil bahwa mahasiswa praktikan berusaha menumbuhkan kepuasan peserta didik dalam mengikuti pembelajaran dengan cara; 1) memberikan pujian (Reward); 2) kesempatan unjuk diri atau kemampuan diri peserta didik; 3) peer learning (membantu teman)

\section{Upaya Optimalisasi Pendidikan Karakter Calon Guru MI Melalui Pendekatan ARCS}

Upaya optimalisasi pendidikan karakter calon guru MI melalui pendekatan ARCS dalam lesson plan bagi mahasiswa PGMI IAIN Syekh Nurjati Cirebon yang mengikuti 
matakuliah micro teaching dapat dikatakan baik, tetapi belum sepenuhnya dapat dilaksanakan secara maksimal yaitu baru mencapai $80 \%$ dengan berbagai kendala ataupun penghambat pelaksanaan model ARCS tersebut. Salah satu upaya optimalisasi tersebut ialah melalui penyusunan lesson plan atau RPP yang merupakan bagian penting dari sebuah silabus. Beberapa aspek pokok yang perlu ada dalam lesson plan yaitu rumusan standar kompetensi, kompetensi dasar, tujuan pembelajaran, indikator keberhasilan, materi pembelajaran, kegiatan pembelajaran, alokasi waktu, metode belajar yang digunakan. dan evaluasi.

Adapun upaya optimalisasi pendidikan karakter calon guru MI melalui pendekatan ARCS dalam lesson plan bagi mahasiswa PGMI IAIN Syekh Nurjati Cirebon yang mengikuti matakuliah micro teaching oleh peneliti dibagi menjadi 3 tahapan utama yaitu: tahap perencanaan, tahap pelaksanaan serta tahap penutup atau evaluasi. Selain tertuang dalam lesson plan atau RPP, konsepsi ARCS juga tertuang dalam capaian mata kuliah micro teaching, sehingga diharapkan mahasiswa mampu memiliki kompetensi: a) nilai/sikap (value/attitude); b) pengetahuan (knowledge) dan c) ketrampilan (skill).

Untuk mengukur kemampuan guru dalam mengembangkan silabus dan lesson plan. dalam penelitian ini peneliti menggunakan Instrumen Penilaian Kinerja, Dalam penelitian ini akan dianalisis dengan menggunakan analisis kualitatif digunakan untuk menganalisis aktivitas guru dan kemampuan guru dalam mengembangkan lesson plan. Pelaksanaan penelitian dilaksanakan sebanyak 3 siklus, setiap siklus terdiri dari 2 kali pertemuan, sehingga keseluruhan siklus selama 6 kali pertemuan dari total 14 pertemuan di luar ujian akhir.

\section{Siklus I}

Berikut penulis paparkan hasil perolehan nilai kemampuan responden dalam mengembangkan Lesson Plan pada Siklus I yang merupakan pengamatan awal tanpa tindakan apapun dari penulis, hasilnya seperti dalam tabel 1 berikut:

Tabel 1. Hasil Belajar Siswa pada Siklus I

\begin{tabular}{llcc}
\hline \multirow{2}{*}{ No } & \multirow{2}{*}{ Nama siswa } & \multicolumn{2}{c}{ Tes siklus I } \\
\cline { 3 - 4 } 1 & DS & Nilai & Ketuntasan \\
\hline 2 & Erl & 75 & Tuntas \\
\hline 3 & Far & 70 & Tidak tuntas \\
\hline 4 & FR & 70 & Tidak tuntas \\
\hline 5 & LL & 70 & Tidak tuntas \\
\hline 6 & MH & 75 & Tuntas \\
\hline 7 & RF & 70 & Tidak tuntas \\
\hline
\end{tabular}




\begin{tabular}{|c|c|c|c|}
\hline 8 & Rud & 70 & Tidak tuntas \\
\hline 9 & SN & 65 & Tidak tuntas \\
\hline 10 & Solh & 70 & Tidak tuntas \\
\hline 11 & Syh & 75 & Tuntas \\
\hline 12 & YM & 70 & Tidak tuntas \\
\hline 13 & ZMU & 65 & Tidak tuntas \\
\hline 14 & $\mathrm{IH}$ & 70 & Tidak tuntas \\
\hline 15 & And & 75 & Tuntas \\
\hline 16 & $\mathrm{AR}$ & 75 & Tuntas \\
\hline 17 & $\mathrm{AL}$ & 70 & Tidak tuntas \\
\hline 18 & FM & - & Tidak tuntas \\
\hline & jumlah 18 siswa & 1205 & \multirow{2}{*}{$\frac{\text { Tuntas } 5}{\text { Tidak tuntas } 13}$} \\
\hline & rata-rata & 71 & \\
\hline
\end{tabular}

Dari tabel 1 dapat diamati bahwa sebagian besar mahasiswa praktikan telah memahami lesson plan. Hal ini terlihat dari kemampuan responden dalam mengembangkan lesson plan dengan perolehan nilai rata-rata kelas sebesar 71. Ada 2 mahasiswa yang mendapat nilai 65 termasuk tingkat keberhasilan dengan predikat "Kurang”. Dari hasil observasi yang dilakukan dapat terlihat 2 mahasiswa calon guru ini mendapat nilai kurang. Hal ini bermakna bahwa pengembangan lesson plan belum berjalan secara optimal sesuai dengan rencana yang telah disusun, banyak kekurangan yang masih perlu diperbaiki pada siklus selanjutnya sehingga dapat meningkatkan proses dan kemampuan responden dalam mengembangkan lesson plan. Kelemahan masih terdapat pada komponen mengembangkan kegiatan pembelajaran, menentukan jenis penilaian, menentukan alokasi waktu dan menentukan sumber belajar.

\section{Siklus II}

Adapun paparan hasil perolehan nilai kemampuan responden dalam mengembangkan Lesson Plan pada Siklus II yang telah mendapatkan beberapa masukan dari penulis yaitu mengembangkan Lesson Plan berdasar kurikulum 2013, dan hasilnya seperti dalam tabel 2 berikut:

Tabel 2. Hasil Belajar Siswa pada Siklus II

\begin{tabular}{llcc}
\hline \multirow{2}{*}{ No } & \multirow{2}{*}{ Nama siswa } & \multicolumn{2}{c}{ Tes siklus II } \\
\cline { 3 - 4 } 1 & DS & Nilai & Ketuntasan \\
\hline 2 & Er & 85 & Tuntas \\
\hline 3 & Far & 80 & Tuntas \\
\hline 4 & FR & 80 & Tuntas \\
\hline 5 & LL & 80 & Tuntas \\
\hline
\end{tabular}




\begin{tabular}{|c|c|c|c|}
\hline 6 & $\mathrm{MH}$ & 85 & Tuntas \\
\hline 7 & RH & 75 & Tidak tuntas \\
\hline 8 & Rud & 75 & Tidak tuntas \\
\hline 9 & $\mathrm{SN}$ & 75 & Tidak tuntas \\
\hline 10 & Sol & 80 & Tuntas \\
\hline 11 & Syh & 75 & Tidak tuntas \\
\hline 12 & YM & 75 & Tidak tuntas \\
\hline 13 & ZMU & 75 & Tidak tuntas \\
\hline 14 & $\mathrm{IH}$ & 75 & Tidak tuntas \\
\hline 15 & And & 80 & Tuntas \\
\hline 16 & $\mathrm{AR}$ & 80 & Tuntas \\
\hline 17 & $\mathrm{AL}$ & 80 & Tuntas \\
\hline \multirow[t]{3}{*}{18} & FM & - & Tuntas \\
\hline & jumlah 18 siswa & 1335 & Tuntas 11 \\
\hline & rata-rata & 78,5 & Tidak tuntas 7 \\
\hline
\end{tabular}

Dari tabel 2 di atas menunjukkan kemampuan responden dalam mengembangkan lesson plan diperoleh rata-rata nilai sebesar 78,5 termasuk tingkat keberhasilan dengan predikat "Cukup". Dari hasil observasi yang dilakukan dapat terlihat 7 orang responden yang memperoleh nilai rata-rata cukup namun belum tuntas hal ini dikarenakan responden tersebut masih belum menyusun lesson plan secara optimal sesuai dengan masukan yang telah direncanakan, sehingga masih ada kekurangan yang masih perlu diperbaiki pada siklus selanjutnya. Kelemahan guru masih terdapat pada komponen menentukan metode, merumuskan langkah-langkah pembelajaran, memilih alat dan sumber belajar serta melaksankan penilaian.

\section{Siklus III}

Paparan akhir ialah terkait hasil perolehan nilai kemampuan responden dalam mengembangkan Lesson Plan pada Siklus III yang telah mendapatkan tindakan dengan mengembangkan sebuah model integrasi dalam lesson plan berbasis ARCS sebagaimana yang penulis kembangkan dalam penelitian ini, dan hasilnya seperti dalam tabel 3 berikut:

Tabel 3. Hasil Belajar Siswa di Siklus III

\begin{tabular}{|c|c|c|c|}
\hline \multirow{2}{*}{ No } & \multirow{2}{*}{ Nama siswa } & \multicolumn{2}{|c|}{ Tes siklus III } \\
\hline & & Nilai & Ketuntasan \\
\hline 1 & DS & 90 & Tuntas \\
\hline 2 & $\mathrm{Er}$ & 90 & Tuntas \\
\hline 3 & Far & 85 & Tuntas \\
\hline 4 & FR & 80 & Tuntas \\
\hline 5 & LL & 80 & Tuntas \\
\hline 6 & MH & 90 & Tuntas \\
\hline 7 & $\mathrm{RF}$ & 85 & Tuntas \\
\hline
\end{tabular}




\begin{tabular}{|c|c|c|c|}
\hline 8 & Rud & 90 & Tuntas \\
\hline 9 & $\mathrm{SN}$ & 90 & Tuntas \\
\hline 10 & Sol & 90 & Tuntas \\
\hline 11 & Syh & 85 & Tuntas \\
\hline 12 & YM & 80 & Tuntas \\
\hline 13 & ZMU & 80 & Tuntas \\
\hline 14 & $\mathrm{IH}$ & 80 & Tuntas \\
\hline 15 & And & 85 & Tuntas \\
\hline 16 & $\mathrm{AR}$ & 85 & Tuntas \\
\hline 17 & $\mathrm{AL}$ & 85 & Tuntas \\
\hline 18 & FM & - & Tuntas \\
\hline & jumlah 18 siswa & 1450 & \multirow{2}{*}{ Tuntas 17} \\
\hline & rata-rata & 85 & \\
\hline
\end{tabular}

Dari tabel 3 dapat dilihat bahwa kemampuan responden mengalami peningkatan. Hal ini terkait dengan motivasi yang diperoleh dari pendekatan ARCS yang diberikan oleh peneliti. Mahasiswa praktikan diajak untuk mengintegrasikan motivasi belajar sebagaimana yang tertuang dalam konsep ARCS. Hal ini terbukti dalam mengembangkan lesson plan diperoleh nilai rata-rata sebesar 85 termasuk tingkat keberhasilan dengan predikat "berhasil". Hanya 1 orang mahasiswa praktikan yang memang sedari awal tidak pernah mengikuti pertemuan micro teaching sama sekali.

Ada beberapa bentuk penugasan yang diberikan oleh peneliti kepada responden selain mengembangkan lesson plan berbasis ARCS, antara lain:

1. Tugas individu

a. Membuat rencana program pembelajaran (RPP) dengan menggunakan model kurikulum 2013.

b. Membuat instrumen penilaian yang meliputi penilaian aspek pengetahuan ( essay / pilihan ganda), penilaian kinerja (daftar check list), instrumentdan penilaian sikap (dalam check list instrument observasi, instrumen angket ).

c. Mempersiapkan media pembelajaran secara optimal sesuai dengan karakteristik materi dan tujuan pembelajaran.

d. Memiliki lembar penilaian untuk praktek mengajar, memiliki lembar penilaian dokumen RPP, memiliki lembar penilaian diri (self evaluation) terkait teacher comperence profile.

2. Tugas kelompok

Membuat laporan portopolio hasil observasi kegiatan pengenalan lapangan persekolahan (PLP) yang meliputi : 

a. Contoh dokumen RPP guru sesuai dengan bidang studi.
b. Laporan hasil observasi terkait dengan belajar mengajar siswa.
c. Laporan hasil wawancara dengan guru terkait dengan problem dan solusi pengelolaan pembelajaran pada bidang studi yang diampu.

\section{Implikasi Pendidikan Karakter Calon Guru MI Melalui Pendekatan ARCS}

Terdapat beberapa implikasi pendidikan karakter calon Guru MI melalui pendekatan ARCS dalam Lesson Plan bagi mahasiswa PGMI IAIN Syekh Nurjati Cirebon yang mengikuti matakuliah micro teaching, diantaranya adalah pada aspek pendukung dan kendala.

a. Pendukung

1) SDM para pengajar yang professional dan berkualitas yang sangat menentukan keberhasilan pembelajaran.

2) Adanya semangat dan kemauan peserta didik untuk belajar sehingga mempermudah guru dalam memberikan motivasi.

3) Adanya peningkatan prestasi belajar karena mereka mulai memperhatikan materi pelajaran.

4) Adanya perangkat pembelajaran yang memadai dalam menunjang pembelajaran seperti: metode pembelajaran, media, laboratorium, ruang multimedia, dan sarana penunjang lainnya.

b. Kendala

1) Terbatasnya jam pelajaran micro teaching terutama jam pelajaran PAI yang menyebabkan guru tidak leluasa dalam memberikan materi yang berupa praktek.

2) Adanya perbedaan :latar belakang peserta didik, latar belakang pendiidkan orang tua peserta didik, lingkungan tempat tinggal, pemahaman agama, motivasi sekolah.

3) Keharusan adanya SDM para pengajar yang professional dan berkualitas yang sangat menentukan keberhasilan pembelajaran

\section{SIMPULAN}

Berdasarkan hasil penelitian, maka dapat ditarik kesimpulan sebagai berikut:

1. Pola optimalisasi pendidikan karakter melalui pendekatan ARCS dalam lesson plan bagi mahasiswa PGMI IAIN Syekh Nurjati Cirebon yang mengikuti matakuliah micro teaching dengan dukungan peneliti telah mengoptimalkan model ARCS dalam kelas praktik pada saat siklus ketiga, salah satunya dengan berusaha membangkitkan perhatian, menunjukkan hubungan materi pelajaran dengan kebutuhan, meningkatkan rasa percaya diri dan menciptakan kepuasan peserta didik dalam pembelajaran. 
2. Upaya optimalisasi pelaksanaan model ARCS dalam pembelajaran di kelas dapat dikatakan baik, karena berhasil meningkatkan hasil belajar siswa yang semula nilai rata-rata siswa sebesar 71, pada siklus III nilai rata-rata siswa menjadi 85 .

3. Implikasi pendidikan karakter calon guru MI melalui pendekatan ARCS dalam lesson plan bagi mahasiswa PGMI IAIN Syekh Nurjati Cirebon yang mengikuti matakuliah micro teaching diantaranya adalah pada aspek pendukung dan kendala. Pada aspek pendukung dari para pengajar yang profesional dan berkualitas sangat menentukan keberhasilan pembelajaran. Adanya semangat dan kemampuan peserta didik untuk belajar sehingga mempermudah guru dalam memberikan motivasi, adanya peningkatan komunikasi belajar karena mereka mulai memperhatikan materi pelajaran. Adapun aspek kendala adalah terbatasnya jam pelajaran micro teaching terutama jam pelajaran PAI yang menyebabkan guru tidak leluasa memberikan materi berupa praktek, adanya berbagai perbedaan dalam beberapa hal yaitu latar belakang peserta didik, latar belakang pendidikan orangtua peserta didik, lingkungan tempat tinggal, pemahaman agama dan motivasi sekolah serta adanya keharusan SDM para pengajar yang profesional dan berkualitas.

\section{DAFTAR PUSTAKA}

Arikunto, S. (2008). Metodologi Penelitian Suatu Pendekatan Praktek. Jakarta: PT Rineka Cipta.

Berkowitz, M.W, and Bier, M.C. (2005). What Works In Character Education: A ResearchDriven Guide for Educators. Washington DC: Univesity of Missouri-St Louis.

Freeman, G. G. (2014). The Implementation of Character Education and Children's Literature to Teach Bullying Characteristics and Prevention Strategies to Preschool Children: An Action Research Project. Early Childhood Education Journal, 305-316. https://doi.org/10.1007/s10643-013-0614-5

Goleman, D. (1995). Emotional Intelligence. USA: Harvard University Press (diterjemahkan oleh PT Gramedia Pustaka Utama: Jakarta, 2000)

Helmawati. (2014). Pendidikan Keluarga, Teoretis dan Praktis. Bandung: Remaja Rosdakarya Offset

Hernawan, dkk. (2009). Pengembangan Kurikulum dan Pembelajaran. Jakarta: Universitas Terbuka

Kasbolah, K. (1998). Penelitian Tindakan Kelas. Malang: Depdiknas

Keller, J.M. (2010). Motivational Design for Learning and Performance: The ARCS Model Approach. New York: Springer

Lickona, T. (1991). Educating for Character: How Our School Can Teach Respect and Responsibility. New York, Toronto, London, Sydney, Aucland: Bantam books

Maswardi. (2011). Pendidikan Karakter Anak Bangsa. Jakarta: Baduose Media

Mulyasa, E. (2009). Praktik Penelitian Tindakan Kelas. Bandung : Remaja Rosdakarya

Munthe, B. (2009). Kunci Praktis Desain Pembelajaran. Yogyakarta: Sukses Offset 
Permendikbud Nomor 23 Tahun 2015 tentang Penumbuhan Budi Pekerti

Power, F. C., \& Seroczynski, A. D. (2015). Promoting Character Development Through Coach Education. Journal of Character Education, 11(2), 87-107.

Sariono. (2013). Kurikulum 2013 : Kurikulum Generasi Emas. Jurnal Dinas Pendidikan Kota Surabaya, 3, 1-9.

Suyadi. (2016). Strategi Pembelajaran Pendidikan Karakter. Bandung: Remaja Rosdakarya.

Uno, H. B. (2006). Profesi Kependidikan; Problema, Solusi dan Reformasi Pendidikan di Indonessia. Jakarta : Bumi Aksara.

Wibowo, A. (2012). Pendidikan Karakter: Strategi Membangun Karakter Bangsa Berperadaban. Yogyakarta: Pustaka Pelajar

Wu, P., Tsai, C., Yang, T., Huang, S., \& Lin, C. (2012). Using ARCS Model to Promote Technical and Vocational College Students' Motivation and Achievement. The International Journal of Learning, 18(4), 79-91 